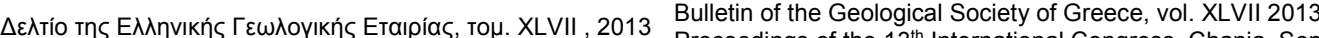
Proceedings of the $13^{\text {th }}$ International Congress, Chania, Sept.

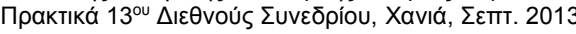
2013

\title{
ENVIRONMENTAL MONITORING OF SOIL POLLUTION IN URBAN AREAS (A CASE STUDY FROM HERAKLION CITY, CENTRAL CRETE, GREECE)
}

\author{
Kokinou E. ${ }^{1}$, Belonaki C. ${ }^{1}$, Sakadakis D. ${ }^{1}$ and Sakadaki K. ${ }^{1}$ \\ ${ }^{1}$ Technological Educational Institute Crete, Department of Natural Resources \& Environment, \\ Chania,Crete,Greece,ekokinou@chania.teicrete.gr
}

\begin{abstract}
Main scope of the present study is to combine topographic and geological data, magnetic susceptibility and thermomagnetic analysis in order to investigate the magnetic properties of the near surface soils in possible polluted urban areas. For this purpose, a power plant with a dense traffic net around it, located in the $N W$ section of Heraklion city in Crete was selected to be the study area. Surface soil samples have been collected from the area under investigation and they were analyzed in order to estimate the spatial distribution of the magnetic susceptibility. Loci of high values of the magnetic susceptibility within the study area gave rise to further proceed to thermomagnetic analysis of the selected samples. GIS techniques were used for mapping the magnetic measurements on the various topographic and geological features of the area. The digital elevation model was created by the digitization of the topographic map contours (1:5000 scale maps). The combination of the above techniques indicate high values of the magnetic susceptibility especially in the northeastern part of the investigated area, possibly related to pollution due to the presence of heavy metals.
\end{abstract}

Key words: Magnetic susceptibility, thermomagnetic analysis, GIS.

\section{Пєрí $\eta \psi \eta$}

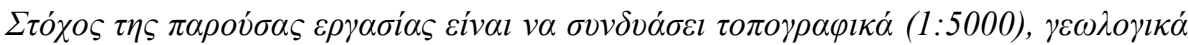

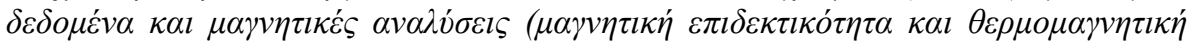

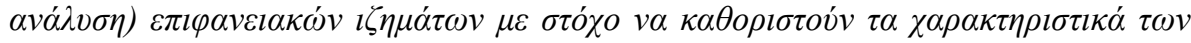

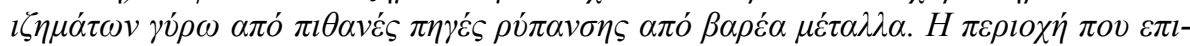

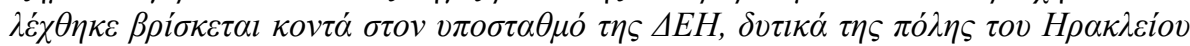

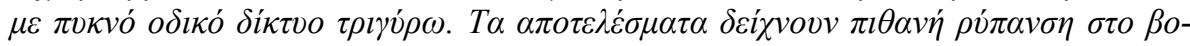


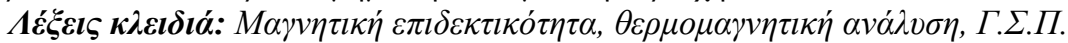

\section{Introduction}

Industrial pollution and heavy traffic constitute serious problems for fast developing countries. Magnetometry and especially magnetic susceptibility is a fast and cost-effective method for detection of environmental pollution of soils, sediments and dusts. Magnetic minerals present in soils may be either inherited from the parent rocks (lithogenic origin), formed during pedogenesis or may be stemmed by anthropogenic activities (emissions from power plants, combustion of

$\underline{\text { XLVII. No } 2-963}$ 
fossil fuel, metallurgical industries, smelters, road traffic, etc.). In the case of minor contribution of the first two sources to the magnetic properties of soils, susceptibility measurements become very important for monitoring environmental pollution, because metallurgical dusts, fly ashes and cement dust contain relatively large amount of iron phases and are therefore highly magnetic (Strzyszcz et al. 1996; Goluchowska 2001). Magnetic particles are usually deposited downwind from the industrial units on the surface of soils, streets, buildings and trees. Fly ashes with significant portion of magnetic minerals are produced by industrial processes; they are transported through atmospheric pathways and deposited on the ground. In soils, such particles penetrate downwards and accumulate in top layers and their increased concentration can be easily detected using surface magnetic measurements. Hansen et al. (1981) indicated that chromium manganese, cobalt, nickel, copper, zinc and beryllium are all significantly enriched in the 'magnetic' fraction of coal fly-ash. Beckwith et al. (1984) identified pollution sources in urban drainage systems using magnetic methods. Petrovsky \& Elwood (1999) reviewed the application of magnetic susceptibility measurements in various ecosystems. Lately, more researchers investigate the usage of magnetic susceptibility as a tool for contaminated top soils and sediments (Scholger 1998; Bitykova et al. 1999; Petrovsky et al. 2001; Boyko et al. 2004, Sarris et al., 2009).

The aim of this study is to establish links between enhanced concentrations of anthropogenic magnetic particles and known sources of pollution in the catchment area. For this purpose the spatial distribution of the magnetic susceptibility and the frequency dependent susceptibility, thermomagnetic analysis, topographic and geological data are combined. This study tries to document that simple and fast in situ magnetic measurements can reflect the anthropogenic influence under certain circumstances.

\section{Geology of the Study Area}

The Heraklion basin (Figure 1a), where the study area is located (Figure 1b), comprises the largest Neogene basin $\left(900 \mathrm{~km}^{2}\right)$. The Neogene deposits of Heraklion basin overlie basement rocks of the Upper Nappes (Gavrovo-Tripolis, Pindos and the heterogeneous Uppermost Unit). The Upper Nappes in the Psiloritis and Dikti Mts. are separated from the HP-LT metamorphic rocks of the Lower Nappes (parautochtone Plattenkalk and Phyllite-Quarzite units) by the Cretan detachment (Zachariasse et al., 2011). This fault (or faults) is in many places exposed with a sense of shear either to both S and N (Kilias et al., 1994; Fassoulas, 1999; Papanikolaou and Vassilakis, 2010), or dominantly top-to the north (Jolivet et al., 1996). This basin is mainly filled by fluvial and marine sediments of Holocene, Pleistocene, Lower-Middle Pliocene, Upper Miocene, Cretaceous Middle Eocene and Upper Triassic-Upper Jurassic (Figure 2). The Holocene sediments (al) mainly comprise fluvial and closed basin deposits, situated in the western part of the city, on either site of the drainage network. Pleistocene - Holocene sediments (Qs) are generally located across the coastline, comprising of undivided marine terraces and coastal sands. The Heraklion formation (Pt) of Pleistocene consists of marine bioclastic limestones, sandstones with crossed bedding conglomerates and marls. The majority of the basin's interior consists of Lower-Middle Pliocene sediments (Pl.m) the so called Finikia formation, comprising of white marls or marly limestones, grayish clays with brown, often thin bedded intercalations, white beige fossiliferous marls, lamellar marls or diatomites and bioclastic limestones. The base of this formation consists in general of an unsorted "marly breccia". It overlies unconformably the Ag. Varvara formation (Mk) of Upper Miocene, consisting of bioclastic, reef limestones, marls or marly limestones $(\mathrm{Mm})$ and gypsum (g). In the eastern part of Heraklion city are situated Cretaceous - Middle Eocene (Ks-Ek) limestones, grey to black, medium-thick bedded to massive bituminous locally microbreciatted and dolomitic in the upper members. Triassic -Upper Jurassic (Ts-Js.Kd) limestones, dolomitic limestones and dolomites are also present in the area. They constitute the base of the external zones tectonic nappe resulting in a local mylonitization at their base due tectonism. They are karstic, mainly in the upper members. Finally the oldest layer of this area is the PhyllitesQuartzites (ph) unit, aged Upper Palaeozoic - Upper Triassic (Krahl et al. 1983), underlain by the 
Plattenkalk unit (Crete-Mani), aged Upper Palaeozoic - Lower Oligocene (Psonis 1981, Thiebault 1982, Manutsoglu 1990, Aleweld 2002).

The study area (Figure 1c-f) is located at the W section of the Heraklion city in Crete, showing a NE-SW orientated drainage network (Figure 2), named Almyros river, located near to the local power plant. The study area is mainly filled by recent alluvial (al) and Pleistocene (Pt.tm) sediments, the Finikia Formation (Pl.m), as well Triassic -Upper Jurassic (Ts-Js.Kd) limestones and the Phyllites-Quartzites (ph) unit. N-S, NW-SE and E-W trending faults prevail in the wide area.

\section{Methodology}

\subsection{Soil Sampling}

Top soil sampling was performed in the study area within a grid covering a total area of about 2.5 $\mathrm{km}^{2}$. GPS coordinates (in EGSA_87 system) were taken from each sampling site in order to be in agreement with the available topographic data. At each site samples were taken within a depth of 0-15 cm below the surface. Soil samples were placed in plastic containers. Each of the soil samples was mixed, air-dried, disaggregated and sieved retaining the fraction smaller than $2 \mathrm{~mm}$ in order to reduce the biasing effect of air, water and pebbles.

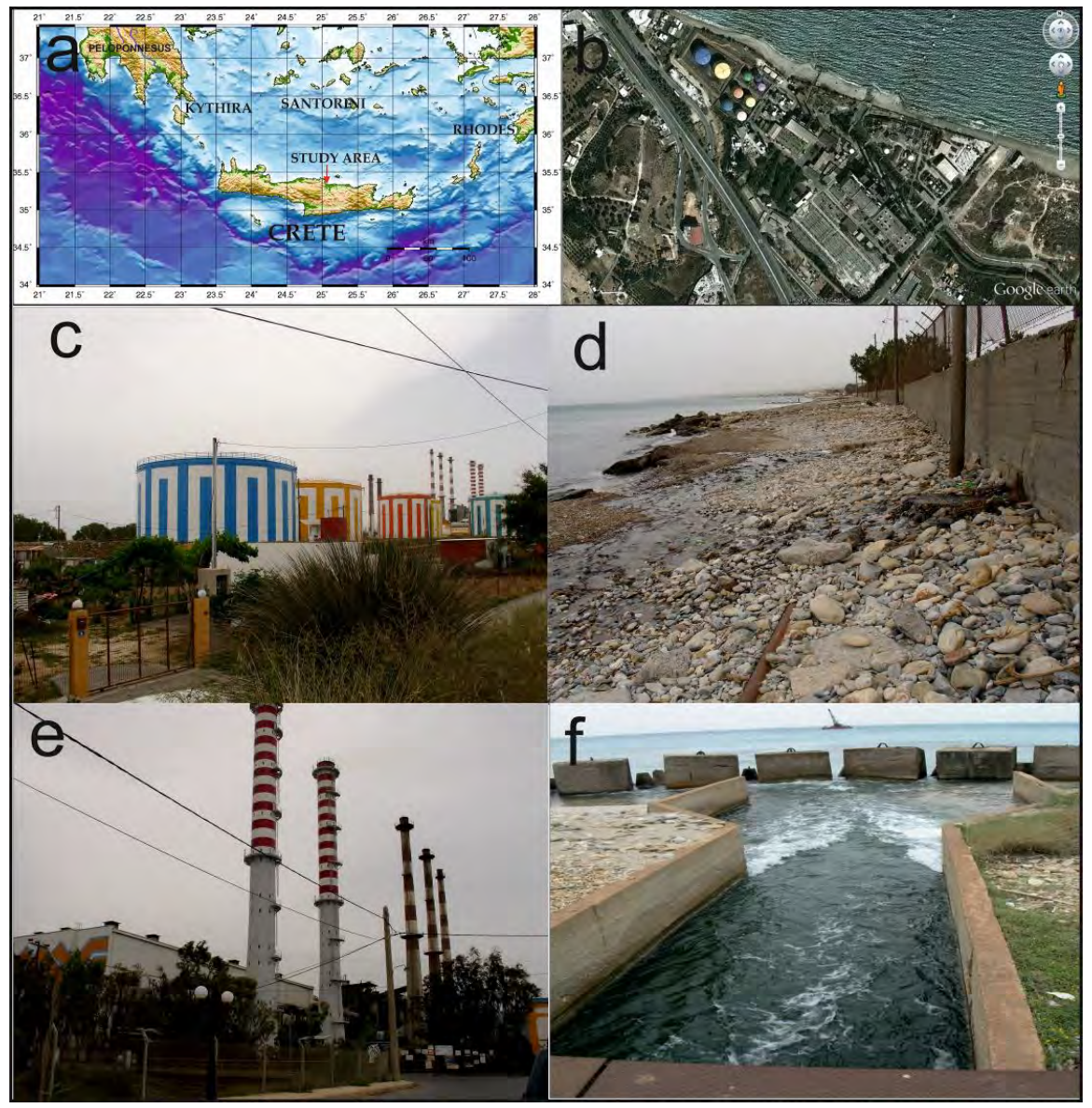

Figure 1 - a: Map of Crete showing the study area, b: the location of the power plant. Satellite imagery from Google Earth showing the wider area of interest, c-f: Detailed photos from the study area.

XLVII. No $2-965$ 


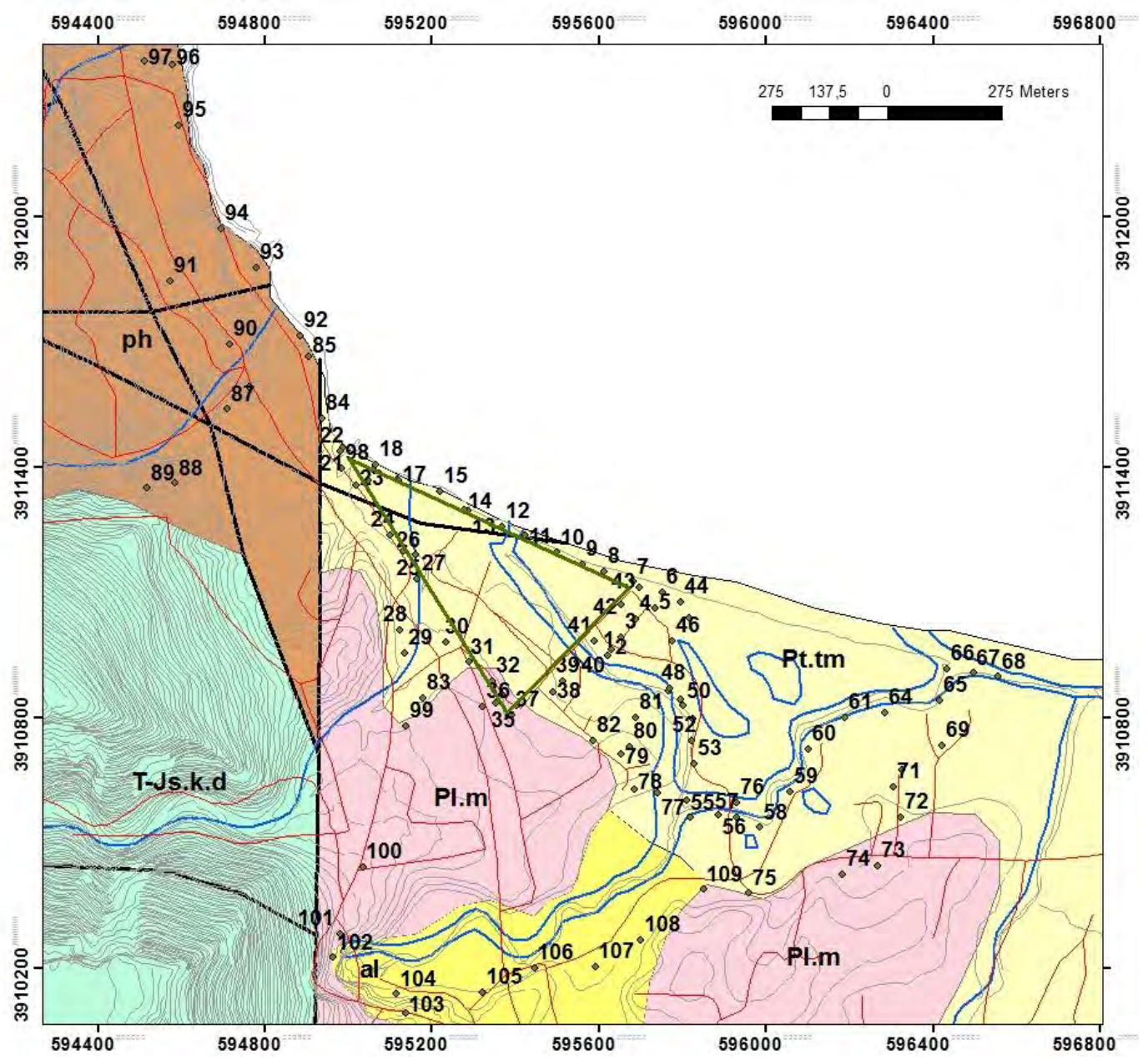

Figure 2 - Geological map of the wider area (according to geological map of IGME). Sympols: al-alluvial sed., Pt.tm-marls, sands and conglomerate, Pl.m- Finikia formation, Ts-

Js.Kd - Triassic -Upper Jurassic limestones, dolomitic limestones and dolomites., phphyllites, Black line-fault, blue line-drainage net, Green line -power plant, Red line - traffic net, Black circle-sample location.

\subsection{Magnetic Measurements}

In environmental magnetism, the most often used magnetic parameter is the magnetic susceptibility $(\chi)$ which is the ratio of induced (temporary) magnetization acquired by a sample in the presence of a weak magnetic field, to the applied field itself. In the present study, the magnetic susceptibility of all samples was measured with the dual frequency version of sensor MS2B (Bartington Instruments). Accurate measurements of mass susceptibility were obtained in two frequencies ( $\mathrm{f}_{\text {low }}=0.43 \mathrm{KHz}$ and $\mathrm{f}_{\text {high }}=4.3 \mathrm{KHz}$ ). Further the frequency dependent susceptibility $\left(\chi_{\mathrm{fd}} \%\right)$ was calculated using the formula: $\chi_{\mathrm{fd}}(\%)=\left[\left(\chi_{\mathrm{lf}}-\chi_{\mathrm{hf}}\right) / \chi_{\mathrm{lf}}\right] \times 100$, where $\chi_{\mathrm{lf}}$ the susceptibility measured in low frequency and $\chi_{\mathrm{hf}}$ the susceptibility measured in high frequency.

Since our samples were of unknown density, mass specific measurements seemed to be more appropriate than the ones based on specific volume. A sample of $10 \mathrm{~cm}^{3}$ tightly packed Manganese Carbonate powder $\left(\chi=99.2 \times 10^{-6} \mathrm{emu} / \mathrm{gr}\right)$ was used for calibration of the instrument. The consistency of the instrument calibration was checked by measuring the susceptibility of the 
calibration sample in the beginning and end of the measuring session. Samples were weighted and the subsequent susceptibility measurements in both frequencies were multiplied by a factor $\mathrm{wf}_{\mathrm{f}}=$ (10/ weight of sample) in order to normalize our measurements for a mass of 10 gr. The contribution of the plastic container was measured for 10 pieces and the average value was subtracted from all measurements.

The magnetic behavior of many minerals varies with temperature. All magnetic minerals have a temperature point (Curie temperature) above which they become paramagnetic. So, in practice, from the shape of the temperature - susceptibility curves the presence of magnetic minerals and domains can be detected. Our samples were heated with the Susceptibility Temperature Bartington Device up to $700^{\circ} \mathrm{C}$ and cooled down to room temperature in order to identify the main magnetic

\subsection{Geographic Information System (GIS)}

Digitization techniques and GIS were applied for the presentation of the spatial distribution of magnetic susceptibility measurements on the topographic and geological data. In order to address the correlation between the above quantities and the geomorphologic attributes of the region, a number of maps were collected and digitized. Topographic maps of the area (scale 1:5000) were enriched through a generalization of the geological formations of the region available by 1:50000 scale geological maps of the Institute of Geological and Mineral Exploration (IGME, Vidakis et al., 1996). Faults, the Almyros river, the main and secondary roads were also digitized and fused to the Geographical Information System component of the project. The samples' location was also superimposed on the maps (Figures. 2, 3, 4).

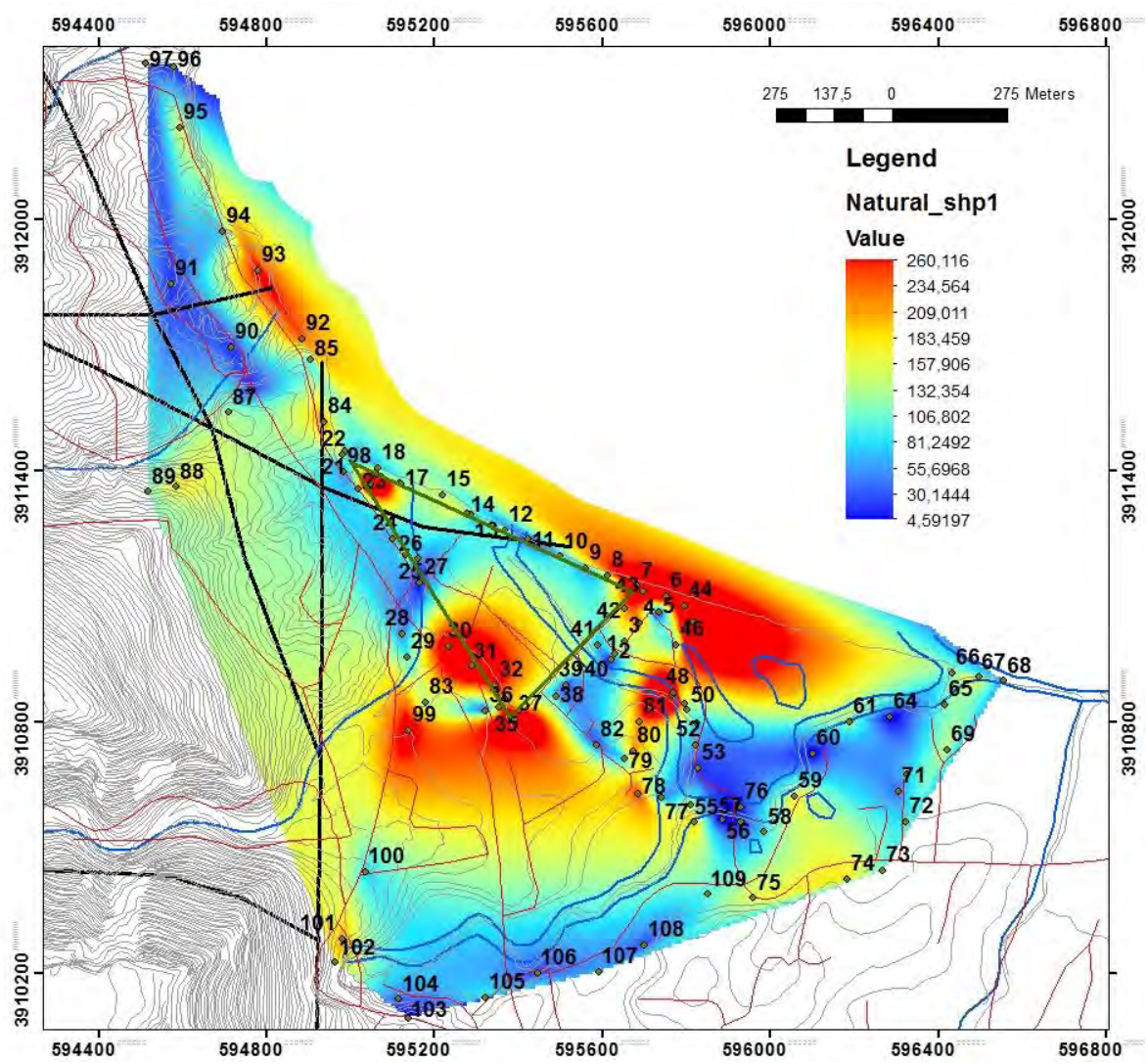

Figure 3 - Spatial distribution of the low field magnetic susceptibility (LFS) in 10-6 m3/Kg. Black line-fault, blue line-drainage net, Green line -power plant, Red line - traffic net, Black circle-sample location.

XLVII. No 2 - 967 


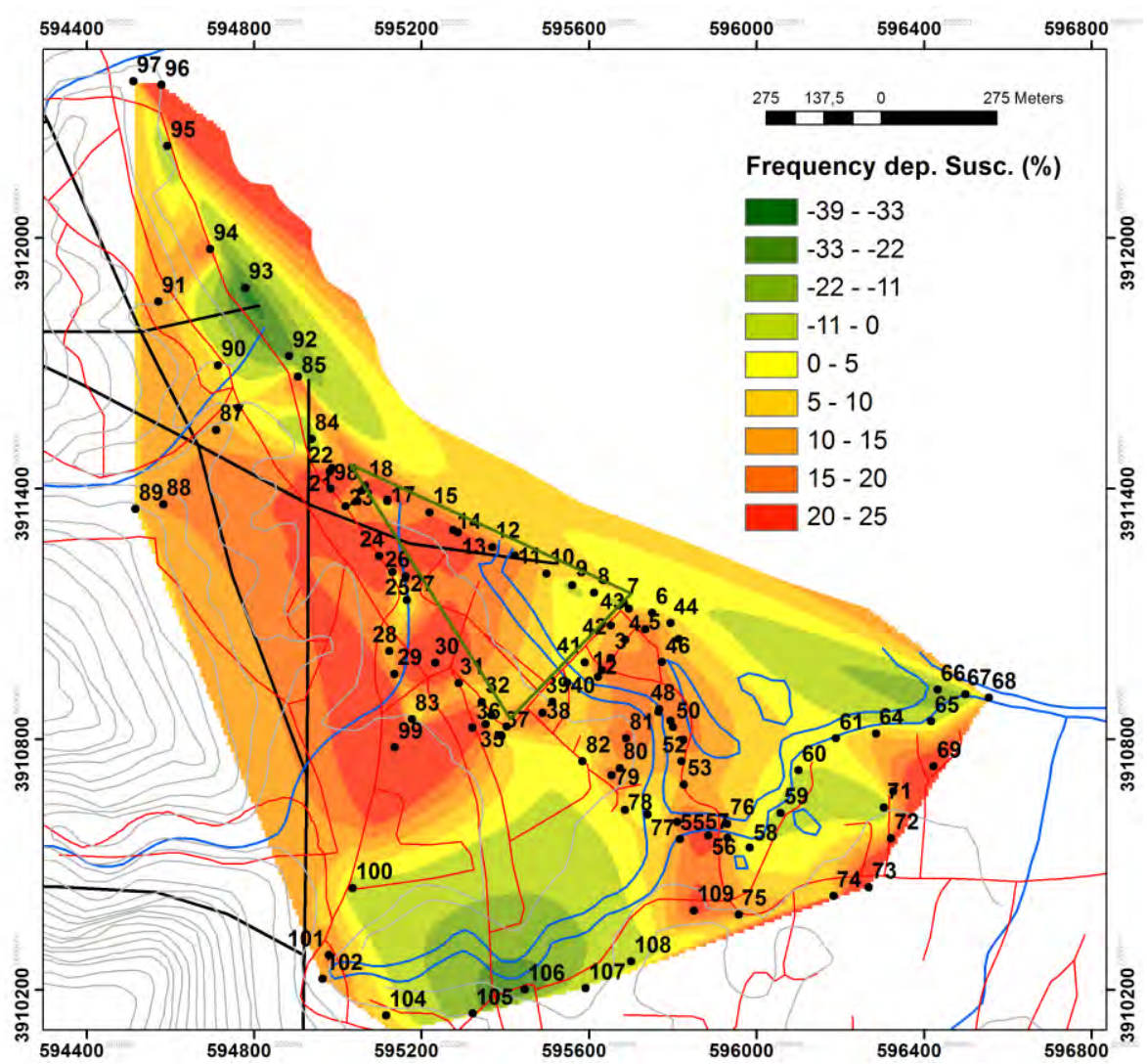

Figure 4 - Spatial distribution of the frequency dependent susceptibility $\chi \%$. Black line-fault, blue line-drainage net, Green line -power plant, Red line - traffic net, Black circle-sample location.

The digital elevation model was created by the digitization of the topographic map contours, while the cell size of the digital elevation model was $4 \mathrm{~m}$. Gridding of the data was carried out using the inverse distance weighted method or the natural neighbor. Similar interpolation methods were used for creating surfaces of the spatial distribution of magnetic measurements.

\section{Results and Discussion}

In the present work, magnetic susceptibility and thermomagnetic measurements were conducted around a power plant with a dense traffic net, located in the W section of Heraklion city in Crete, in order to examine if the study area is an interesting place for further pollution research. The relief of the study area is steep in the western part and almost flat in the eastern part. From the geological point of view, the majority of the collected samples mainly correspond to Pliocene-Pleistocene and alluvial sediments. A few of them have been collected from the western most area covered by the Phyllites-Quartzites unit.

The distribution of the low frequency magnetic susceptibility (LFS) is presented in Figure 3. High susceptibility values, indicating possibly polluted sites, are generally detected around the power plant and across the coast. The majority of the samples selected across the drainage net show relative low $\chi$. High frequency magnetic susceptibility (HFS) presents the same distribution as the low one. The distribution of the frequency dependent susceptibility $(\chi \mathrm{fd} \%)$ shows low values (less than $5 \%$ ) upstream of Almyros river and at the lower part of the high order branch. High values 
(up to $25 \%$ ) of the $\chi_{\mathrm{fd}} \%$ are indicated west of the power plant and at the stream of Almyros river in the vicinity of the power plant (Figure 4).

Additionally, thermomagnetic analysis indicate the presence of magnetite (Figure 5, samples 72, 102 and possibly 74 ) as the main magnetic mineral in the samples as well the contribution of hematite (Figure 5, sample 107). Samples, corresponding to the same geological formations and showing low magnetic susceptibility values, generally present paramagnetic behavior (Figure 6).

Presently, the morphology of the landward coastal region in the wide area of study shows alterations between small hills and small flat fields, up to the distance of 150-170 meters from the coastline. Around the study area, the relief of the coastal area is smoother including an extensive sandy beach, while southwards the relief is hilly. Concerning the geological structure of the study area, faults seem not to be related to the pollution transport. The main transmission factor in the study area seems to be the wind. The extensive nearly straight front of the coast, is unprotected from the north sector winds (mainly northern, north-eastern and partly north-western winds) (Pehlivanoglou and Papathanasoglou, 2004). High values of the magnetic susceptibility $\chi$ are orientated NW-SE that is the orientation of the study area. Northern and north-western winds usually blow in this area. The hilly relief southwards may prevent the pollution transmission to this direction. Low values of the magnetic susceptibility $\chi$ are mainly distributed in the southeastern part of the study area, even though the drainage network is also well developed in this part of the study area.

The results of our investigation generally confirm that magnetic susceptibility measurements provide the basis for an environmental study in polluted areas. Furthermore, the terrain attributes and the wind currents seem to play also an important role in the distribution of the possible pollution. In this term GIS techniques provide an excellent tool for studying the spatial distribution and relation between magnetic susceptibility, pollution mainly due to the presence of heavy metals and the natural settings of a study area.

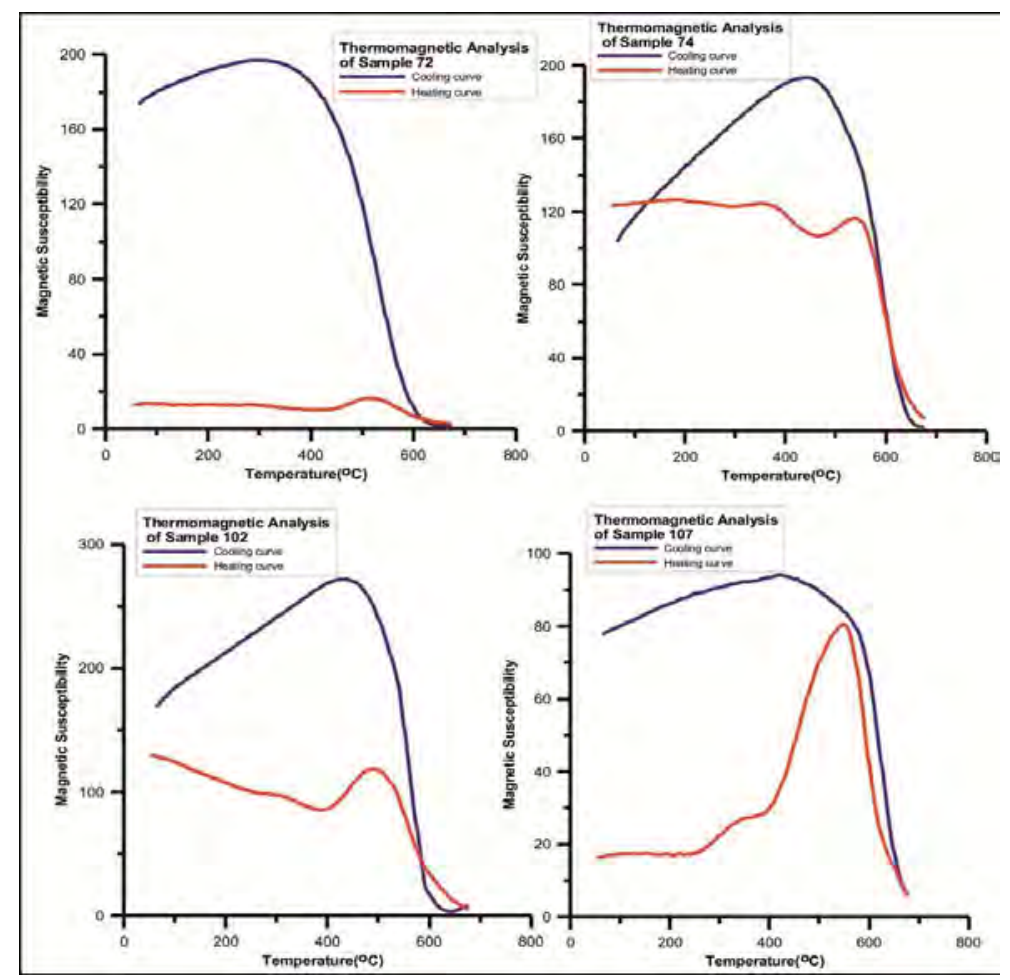

Figure 5 - Thermomagnetic curves of samples showing magnetic behavior.

$\underline{\text { XLVII. No } 2-969}$ 


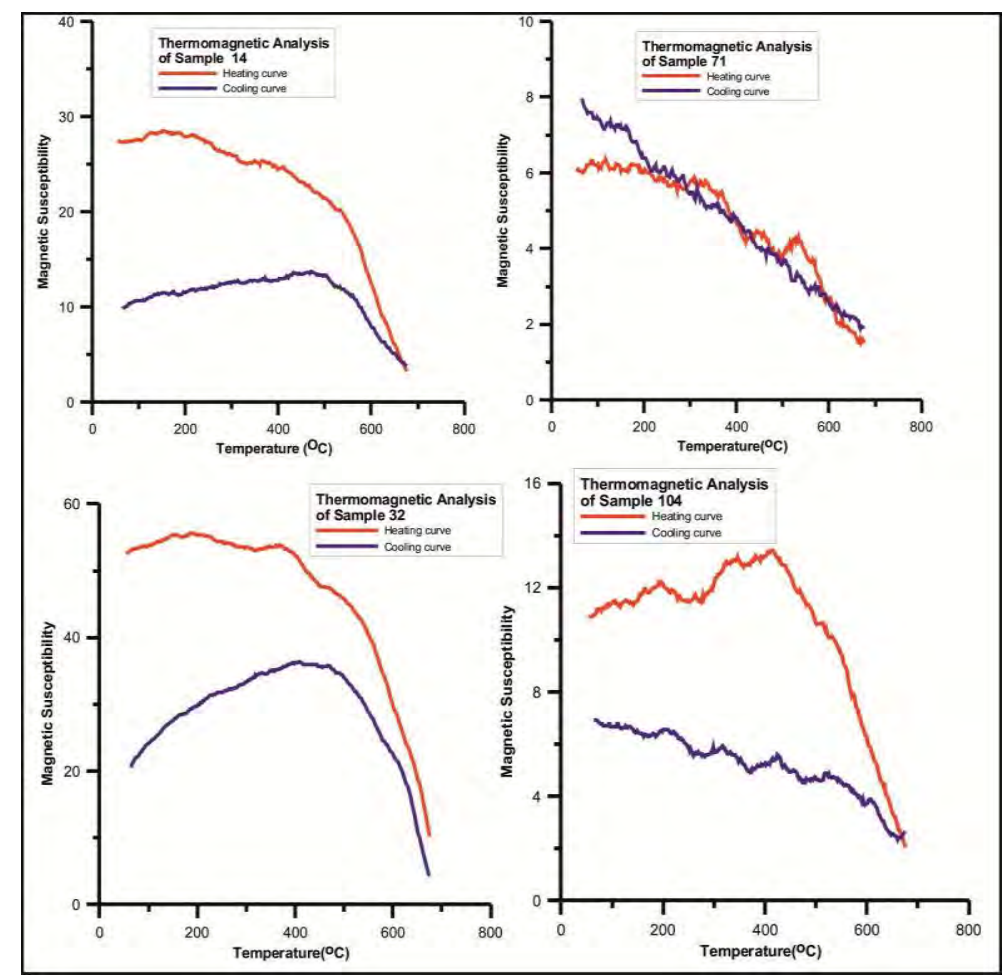

Figure 6- Thermomagnetic curves of samples showing paramagnetic behavior.

\section{Conclusions}

Strong contribution of the morphology and the wind currents to the pollution transport is considered for the study area. In concluding, the study area is of interest and further magnetic analyses (IRM, ARM, hysteresis loops) as well chemical analyses are proposed in order to examine the possibly polluted sites. In any case, the application of the magnetic methods should not be overestimated. Results obtained in one specific region may not be applicable to another region. Instead, detailed analysis should be carried out in order to establish basic correlations between various magnetic parameters, possible pollution (concentration of heavy metals) and natural settings. Only if such relationship is evident, magnetic measurements can be used in tracing and observing temporal and spatial variations of the pollution.

\section{Acknowledgements}

We would like to thank Professor Manutsoglou E. and Lecturer Aidona E. for their critical reviews, which help improved the manuscript.

\section{References}

Aleweld E. 2002. Seriengliederung und Deckenbau im nördlichen Taygetos-Gebirge (Südpelopon nes, Griechenland), $P h D$ thesis, Universität Müchen, München, 150 pp.

Beckwith P.R. Ellis J.B. Revitt D.M. and Oldfield F. 1984. Identification of pollution sources in urban drainage systems using magnetic methods, in Balmer P., Malmqvist P.A., Sjoberg A., eds.: Proc. of the 3rd International Conference on Urban Storm Drainage, Chalmers University of Technology, Gotenborg, Sweden, 1313-1322.

Bityukova L. Scholger R. and Birke M. 1999. Magnetic susceptibility as indicator of environmental pollution of soils, Tallin/ Phys. Chem. Earth, 24, 829-835.

XLVII. No $2-970$ 
Boyko T. Scholger R. Stanjek H. MAGPROX Team 2004. Topsoil magnetic susceptibility mapping as a tool for pollution monitoring: repeatability of in situ measurements, J. Applied Geophys., 55, 249-259.

Fassoulas C. 1999. The structural evolution of Central Crete: insight into the tectonic evolution of the South Aegean (Greece), J. Geodynam., 27, 23-43.

Goluchowska B.J. 2001. Some factors affecting an increase in magnetic susceptibility of cement dusts, J. Appl. Geophys., 48, 103-112.

Hansen L.D. and Silberman D. and Fischer, G.L. 1981, Crystalline components of stack-collected, size-fractioned coal fly ash, Environ. Sci. Technol., 15, 1057-1062.

Jolivet L. Goffé, B. Monie P. Truffert-Luxey C. Patriat M. and Bonneau M. 1996. Miocene detachment on Crete and exhumation P-T-t paths of high-pressure metamorphic rocks, Tectonics, 15, 1129-1153.

Kilias A., Fassoulas C. and Mountrakis D. 1994. Tertiary extension of continental crust and uplift of Psiloritis metamorphic core complex in the central part of the Hellenic Arc (Crete,Greece), Geol. Rundsch., 83, 417-430.

Krahl J., Kauffmann G., Kozur H., Richter D., Forster O. and Heinritzi F. 1983. Neue Daten zur Bi ostratigraphie und zur tektonischen Lagerung der Phyllit-Gruppe und der Trypali-Gruppe a ufder Insel Kreta (Griechenland), Geol. Rundsch., 72, 1147-1166.

Manutsoglu E. 1990. Tektonik und metamorphose der Plattenkalk-Serie im Taygetos (Peloponnes, Griechenland), Berliner geowiss. Abh. (A), 129, 82 pp.

Papanikolaou D. and Vassilakis E. 2010. Thrust faults and extensional detachment faults in Cretan tectono-stratigraphy: implications for Middle Miocene extension, Tectonophysics, 488, 233-247.

Pehlivanoglou K.G. and Papathanasoglou, A. 2004. Geologic and Oceanographic data determining the "old foreshore zone", of the Heraklion coastal area, Crete Island, Global Nest:the Int. J., 6(2), 157-166.

Petrovský E. and Ellwood B. B. 1999. Magnetic Monitoring of Air-, Land- and Water Pollution, in: B. A. Maher and R. Thompson (eds): Quaternary Climates, Environments and Magnetism, Cambridge University Press, Cambridge, U.K., 279-322.

Petrovsky E. Kapička A. Jordanova N. and Borůvka L. 2001. Magnetic properties of alluvial soils contaminated with lead zinc and cadmium, J. Applied Geophys., 48, 127-136.

Psonis K.T. 1981. About the presence of Permian (?) - Lower Triassic beds as a basement of the P lattenkalk series in the Taygetos Mt. Description of a continuous section, Ann. Geol. Pays. Hell., 30, 578-587.

Sarris A., Kokinou E., Aidona E., Kallithrakas-Kontos N., Koulouridakis P., Kakoulaki G., Droulia K. and Damianovits O. 2009. Environmental study for pollution in the area of the Megalopoli power plant (Peloponnesus, Greece), Environmental Geology, 58, 8, 17691783, DOI:10.1007/s00254-008-1676-3.

Scholger R. 1998. Heavy metal pollution monitoring by magnetic susceptibility measurements applied to sediments of the river Mur (Styria, Austria), Eur. J. Envirn. Eng. Geophys., 3, 25-37.

Strzyszcz Z., Magiera T. and Heller F. 1996. The influence of industrial emissions on magnetic susceptibility of soils in Upper Silesia, Studia Geophysica and Geodesia, 40, 276 - 286.

Thiebault F. 1982. Evolution geodynamique des Hellenides externes en Peloponnese meridional ( Grece), Societe Geologique du Nord, 6, 393 pp.

Vidakis M., Meulenkamp J.E., Koutsouveli A., Ioakim, Ch., Papazeti, E. and Skourtsi-Koronaiou, V. 1996, Geological Map of Greece in 1:50,000 scale - Heraklion Sheet. IGME, Athens.

Zachariasse W.J,. van Hinsbergen, D.J.J. and Fortuin A.R. 2011. Formation and fragmentation of a lateMiocene supradetachment basin in central Crete: implications for exhumationmechanisms of high-pressure rocks in the Aegean forearc, Basin Res., 23, 678-701, doi: 10.1111/j.1365-2117.2011.00507.x. 